\title{
Noradrenaline as a putative neurotransmitter mediat- ing hypotension-induced Fos-like immunoreactivity in the supraoptic nucleus of the rat
}

\author{
SHEN EH, XIA SUN \\ Shanghai Brain Research Institute, Chinese Academy of \\ Sciences, Shanghai 200031, China.
}

\begin{abstract}
Hemorrhage or hypotension induces extensive Foslike immunoreactivity in the magnocellular neurosecretory cells in the supraoptic nucleus of the hypothalamus in rat, especially in the vasopressin neurons. The present study was to explore the neurotransmitter mediating this effect. Microinfusion of the alpha-adrenergic blocker into the supraoptic nucleus reduced the hypotension-induced Fos, whereas beta-antagonist did not affect it significantly. Alpha1- and alpha2-antagonist, prazosin and yohimbine, both reduced the Fos-positive cell counts. However, the effective dosage of yohimbine was much larger. Alpha agonist, methoxamine, induced abundant Fos-like immunoreactivity in the vasopressin cells in this nucleus, while beta- and alpha 2 -agonist did not elicit such effect. Administration of the noradrenergic re-uptake inhibitor, desipramine, to this nucleus to locally accumulate the' spontaneously released noradrenaline from the nerve terminals also induced Fos expression, mostly in the vasopressin cells.
\end{abstract}

Key words: $c$-fos, neurosecretory cells, noradrenaline, supraoptic nucleus, vasopressin.

Correspondence: Eh SHEN, Shanghai Brain Research Institute, 320 Yue-yang Road, Shanghai 200031, China.

Abbreviations: BP, blood pressure; FLI, Fos-like immunoreactivity; NGF, nerve growth factor; NA, noradrenaline; NTS, nucleus tractus solitarius; OC, optic chiasma; OT, oxytocin; PBS, phosphate-buffered saline; PV, paraventricular nucleus; SNP, sodium nitroprusside; SO, supraoptic nucleus; VP, vasopressin. 
NA mediating Fos-induction in vasopressin cells

\section{INTRODUCTION}

Hemorrhage or hypotension induces extensive Fos-like immunoreactivity (FLI) in the paraventricular nucleus (PV) and supraoptic nucleus (SO) of the hypothalamus in the rat[1,2]. Double labeling the FLI-positive cells with anti-oxytocin or antivasopressin serum shows that FLI is mostly expressed in the vasopressin (VP) cells rather than in the oxytocin (OT) cells, especially in the $\mathrm{SO}$ [2]. c-fos is one of the family members of the immediate-early genes which have been implicated as third messengers in the intracellular signal transduction systems[3, 4]. It is of interest to reveal the chemical pathway through which extracellular stimuli initiate the activity of third messengers in different kind of nerve cells. The hypotension-induced FLI expression in the magnocellular neurosecretory neurons may serve as a model. As an initial step, we here investigated the neurotransmitters and receptors involved in the hypotension-induced FLI expression in the supraoptic nucleus.

The preferential expression of FLI in the VP cells of the SO indicates that this effect is induced through a specific neural pathway. A pathway has been demonstrated from the nucleus tractus solitarius, which receives the message of baroreceptor unloading, via the ventrolateral medulla to those portions of the magnocellular divisions of the SO and PV in which VP cells are concentrated[5-9]. The latter part of the pathway has been shown to be noradrenergic. The phasically firing putative VP neurons in the SO and PV are activated by electrical stimulation in both the caudal ventrolateral medulla and NTS[7, 10, 11, 12]. Lesions of noradrenergic cells in the ventrolateral medulla reduce the vasopressin release evoked by hemorrhage[6, 13]. In this context, noradrenaline (NA) seems pertinent to be the first candidate for us to explore, Preliminary work of the present study has been reported in an abstract[14].

\section{MATERIALS AND METHODS}

Male Sprague-Dawley rats (200-300 g) were anesthetized with sodium pentobarbital $(60 \mathrm{mg} / \mathrm{kg}$, i.p.). The right femoral artery was cannulated with a PE 50 tubing which was connected through a pressure transducer to a DC amplifier and pen recorder for measurement of blood pressure (BP). The right femoral vein was cannulated for intravenous infusion of sodium nitroprusside (SNP, 2 $\mathrm{mg} / \mathrm{ml}$ ) to lower the BP when needed. During the hypotension procedure BP was suddenly lowered by a surge of infusion of SNP, then the infusion was kept at a constant rate (10 $\mu \mathrm{l} / \mathrm{min})$.

Rats were divided into 4 control groups and 17 experimental groups ( $\mathrm{n}=5$ or 6 in each group) subjected to different dose of antagonists or agonists (see below). In these experiments the head of the rat was mounted on a Narishge stereotaxic instrument. A microsyringe was fixed on a micromanipulator, and the tip of needle was aimed at $1.4 \mathrm{~mm}$ posterior to bregma, $1.8 \mathrm{~mm}$ lateral to midline, and $9 \mathrm{~mm}$ below the skull surface. The rate of microinfusion was $10 \mathrm{nl} / \mathrm{min}$. The antagonists were microinfused $10 \mathrm{~min}$ before hypotension and continued for another 20 min during and after hypotension. The duration of hypotension in such experiments was kept at $60 \mathrm{mmHg}$ for $15 \mathrm{~min}$, then the BP was returned to normal by stopping the infusion of SNP. Animals were sacrificed $60 \mathrm{~min}$ after the beginning of hypotension. For each antagonist, rats were divided into 3 groups ( $\mathrm{n}=6$ in each group): (1) Control, i.e. saline+hypotension; (2) lower dose+hypotension; (3) higher dose+hypotension. The agonists were microinfused to the SO in the rats without hypotension. In each rat $0.5 \mu \mathrm{l}$ of agonist was given slowly in a period of $50 \mathrm{~min}$, and the animal was sacrificed after 
another $30 \mathrm{~min}$. BP was monitored to make sure the agonist not causing fluctuation of BP For each agonist, rats were divided into 3 groups ( $n=5$ in each group) administrated with lower, middle and higher doses respectively. A separate group $(n=5)$ was microinfused with saline only;

At the end of experiments rats were intracardially perfused with heparinized phosphate-buffered saline (PBS) followed by 4\% paraformaldehyde in PBS. Brains were post-fixed for $2 \mathrm{~h}$, and kept in cool PBS $\left(5^{\circ} \mathrm{C}\right)$ over night, then sectioned coronally at $40 \mu \mathrm{m}$ thickness with a vibratome and processed for immunocytochemistry.

\section{Immunocytochemistry}

For Fos immunocytochemistry the main procedures were as follows. (1) incubation of sections with $10 \%$ normal rabbit serum for 30 rain; (2) incubation with primary antibody to Fos protein (sheep polyclonal antibody, Cambridge OA-11-823, 1:1000 dilution with 0.4\% Triton $\times 100$ in PBS) for $72 \mathrm{~h}$ at $4^{\circ} \mathrm{C}$; (3) incubation with biotinylated rabbit anti-sheep IgG (1:200, Vector) for $2 \mathrm{~h}$; (4) incubation with avidin-biotin-horseradish peroxidase complex (1:100, ABC standard kit, Vector) for $1 \mathrm{~h}$; (5) developing in diaminobenzidine/ $\mathrm{H}_{2} \mathrm{O}_{2}$ solution. Between every two steps the sections were rinsed thoroughly with PBS.

To double-stain the sections for Fos and VP or OT, (1) the sections were incubated in normal rabbit serum as above for blocking non-specific protein-binding groups; (2) incubated in primary anti-Fos serum (from sheep, Cambridge, OA-11-823, 1:1000) mixed with primary anti-VP or antiOT serum (from rabbit, 1:1000; provided by Dr. Changling Lu of the Second Military Medical University at Shanghai. The high specificity of these antisera had been characterized previously $[15,16]$ ) for $72 \mathrm{~h}$ in $4^{\circ} \mathrm{C}$; (3), (4) (5) as above for developing FLI; (6) sections were incubated with biotinylated goat anti-rabbit IgG (1:200, Vector) for $2 \mathrm{~h}$; (7) incubated with avidin-conjugated fluorescein isothiocyanate (1:100, Sigma) for $30 \mathrm{~min}$ to show the VP or OT immunoreactivity. A fluorescence microscope (Leitz) with appropriate filters was used.

As staining controls, the primary antisera were either omitted from the staining procedures or pre-absorbed with antigens, i.e., Fos synthetic peptide (Cambridge, OP-11-3210), argininevasopressin (Sigma) or oxytocin (Sigma). No staining was seen in these controls.

\section{Statistics}

The total FLI-positive cells in the SO on 12 consecutive sections containing SO were counted with a manually operated counter guided by a grid in the eye piece. The data were expressed as means \pm S.D. The results were analyzed by means of Rank Sum test.

\section{Materials}

Sodium nitroprusside (Sigma); phentolamine methanesulfonate (Sigma); prazosin HCl (Sigma, dissolved in dimethylsulfoxide, then diluted to the intended concentration with PBS. The final dilution of dimethylsulfoxide did not exceed $0.01 \% \mathrm{v} / \mathrm{v}$ ); yohimbine $\mathrm{HCl}$ (Sigma); DL-propranolol $\mathrm{HCl}$ (Sigma); methoxamine $\mathrm{HCl}$ (Sigma); clonidine $\mathrm{HCl}$ (Sigma); (-)isoproterenol HCl (Sigma); desipramine $\mathrm{HCl}$ (Sigma).

\section{RESULTS}

\section{Duration of hypotension}

The duration of hypotension employed in previous work for induction of FLI was $1 \mathrm{~h}[2]$. It is not convenient for studying the action of different antagonists, since some drug effect may not last for such a long period. For this reason, the effects of 5 and $15 \mathrm{~min}$ of hypotension were compared with that of $60 \mathrm{~min}$, provided that all animals were perfused at $1 \mathrm{~h}$ after the beginning of hypotension. The counts of 
NA mediating Fos-induction in vasopressin cells

FLI-positive cells induced by 5,15 and 60 min hypotension was $2178 \pm 625,2270$ \pm 448 and $2301 \pm 438$ respectively $(n=5)$, the differences among them being not significant. We used a duration of 15 min hypotension in the following experiments.

\section{Time course of FLI expression}

Given the duration of hypotension being $15 \mathrm{~min}$, animals were perfused respectively at $0,15,30,60,120,180,240,360,480 \mathrm{~min}$ and $24 \mathrm{~h}$ after the beginning of hypotension. Fig 1 shows that the peak of FLI-positive cell counts is at $180 \mathrm{~min}$. At $480 \mathrm{~min}$, it falls almost to the baseline.

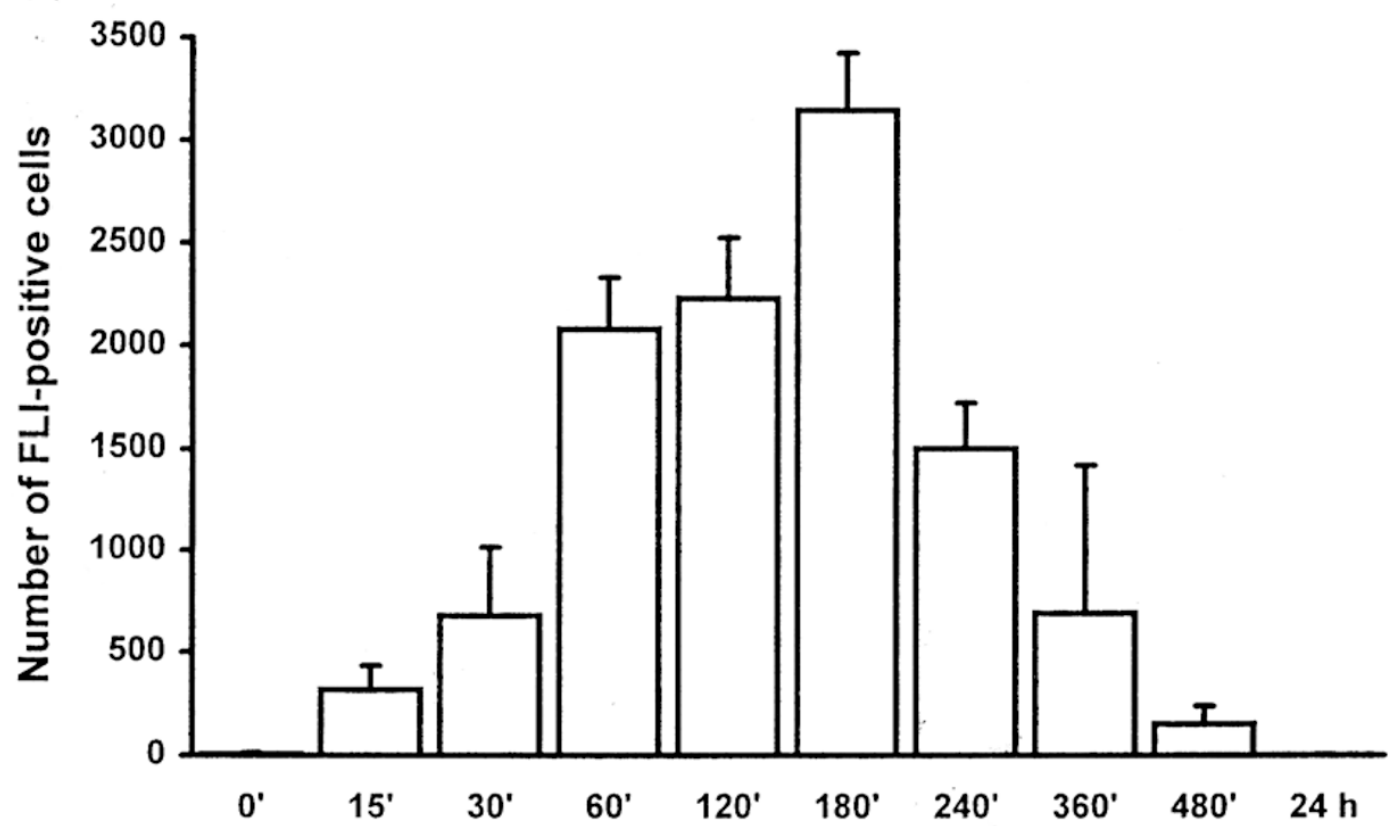

Fig 1. Time course of FLI expression in the supraoptic nucleus shown at $0,15,30,60,120$, $180,240,360,480 \mathrm{~min}$ and $24 \mathrm{~h}$ after the start of $15 \mathrm{~min}$ hypotension. For the data of time zero rats were sacrificed immediately after anesthesia without hypotension treatment, $\mathrm{n}=4$.

Effects of adrenergic antagonists

We tried the $\alpha$-adrenergic antagonist, phentolamine, and $\beta$-adrenergic antagonist, propranolol first. Microinfusion of phentolamine ( 1 and $5 \mathrm{nmol}$ in $0.3 \mu \mathrm{l}, \mathrm{n}=6$ ) directed to the right SO diminished the FLI expression induced by hypotension, whereas microinfusion of propranolol ( 1 and $5 \mathrm{nmol}$ in $0.3 \mu \mathrm{l}, \mathrm{n}=6$ ) did not affect the FLI-positive cell counts significantly (Fig 2, Fig 3). 
Microinfusion of $\alpha_{1}$-antagonist, prazosin $(0.1$ and $0.5 \mathrm{nmol}$ in $0.3 \mu \mathrm{l}, \mathrm{n}=6)$, or $\alpha_{2^{-}}$ antagonist, yohimbine ( 1 and $5 \mathrm{nmol}$ in $0.3 \mu \mathrm{l}, \mathrm{n}=6$ ) both reduced the FLI-positive cell counts (Fig 2, Fig 3). However the effective dosage of yohimbine was higher.

\section{Fig 2.}

Effects of microinfusion of adrenergic antagonists (propranolol, phentolamine, prazosin and yohimbine) into the supraoptic nucleus on the FLI in this nucleus induced by 15 min hypotension. The rats were sacrificed $1 \mathrm{~h}$ after start of hypotension. In the controls $(\mathrm{C})$ the rats were treated by microinfusion of saline into the supraoptic nucleus before and during hypotension. The figure under each column denotes dose in nmol. $\mathrm{n}=6$. * $\mathrm{P}<$ $0.05 ; * *, \mathrm{P}<0.01 ; * * *, \mathrm{P}<0.001$.

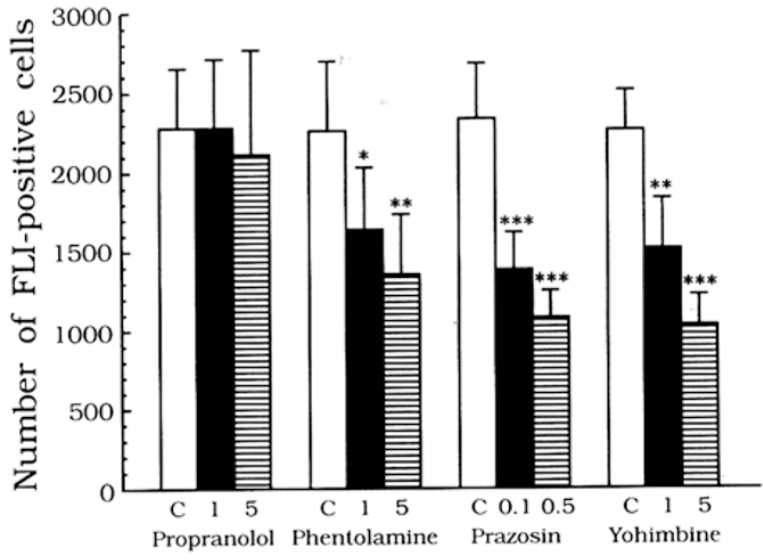

Tab 1. The effect of microinfusion of $0.3 \mu$ l adrenergic antagonists for $30 \mathrm{~min}$ into the supraoptic nucleus on the FLI in this nucleus induced by $15 \mathrm{~min}$ hypotension. For each antagonist the same volume of saline was infused at the same speed into the same nucleus before and during hypotension to serve as control

\begin{tabular}{ccc}
\hline Treatment & $\mathrm{N}$ & Count of FLI-positive cells \\
\hline saline & 6 & $2281 \pm 372$ \\
1 nmol propranolol & 6 & $2282 \pm 430$ \\
5 nmol propranolol & 6 & $2116 \pm 652$ \\
saline & 6 & $2262 \pm 435$ \\
1 nmol phentolamine & 6 & $1639 \pm 395^{*}$ \\
5 nmol phentolamine & 6 & $1355 \pm 381^{* *}$ \\
saline & 6 & $2337 \pm 347$ \\
0.1 nmol prazosin & 6 & $1385 \pm 236^{* * *}$ \\
0.5 nmol prazosin & 6 & $1083 \pm 171^{* * *}$ \\
saline & 6 & $2266 \pm 249$ \\
1 nmol yohimbine & 6 & $1517 \pm 320^{* *}$ \\
5 nmol yohimbine & 6 & $1033 \pm 192^{* * *}$ \\
\hline
\end{tabular}

${ }^{*} \mathrm{P}<0.05 ;{ }^{* *} \mathrm{P}<0.01 ;{ }^{* * *} \mathrm{P}<0.001$. 
NA mediating Fos-induction in vasopressin cells
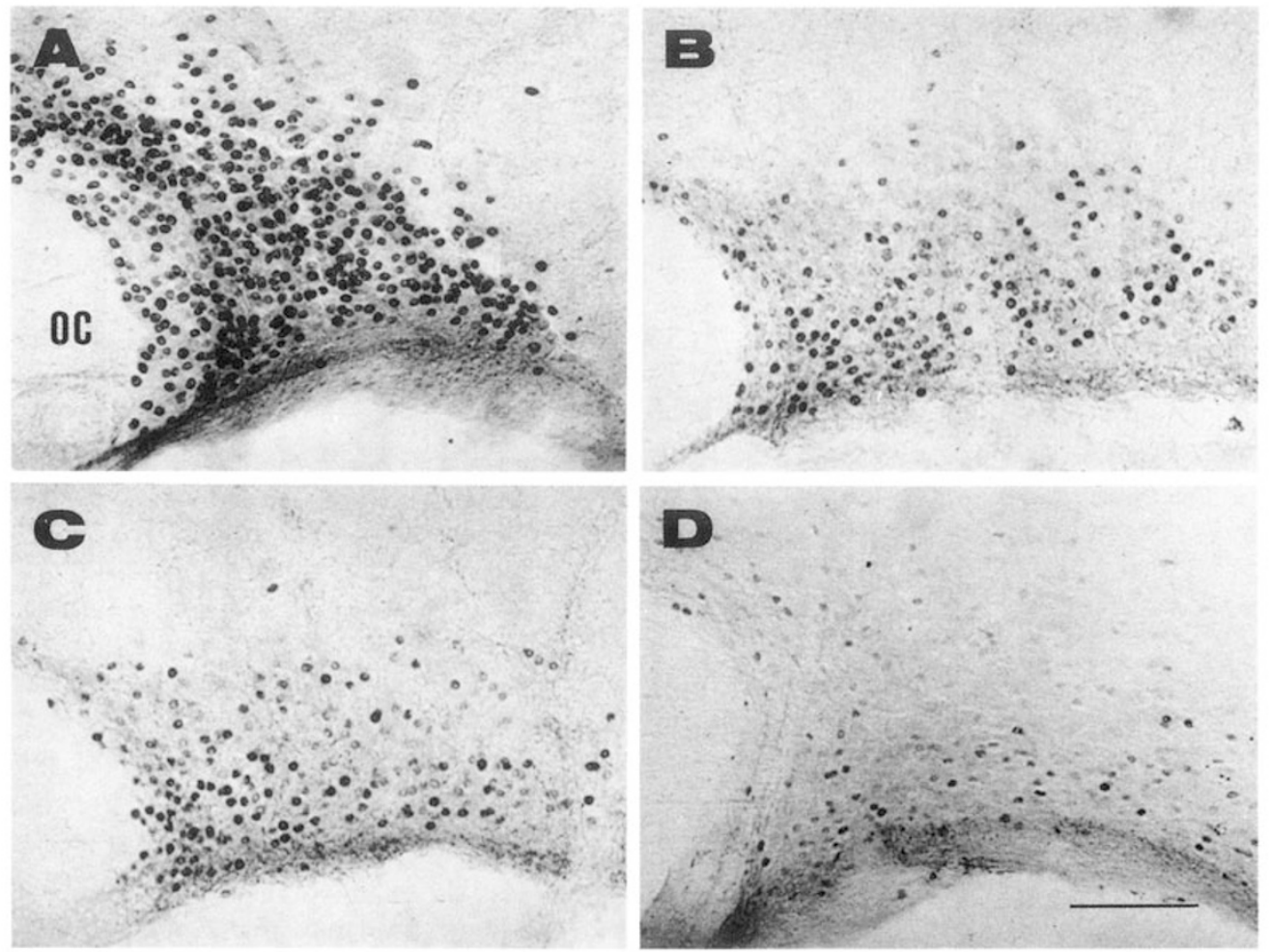

Fig 3. Photomicrographs of the right supraoptic nucleus showing the effects of microinfusion of $5 \mathrm{nmol}$ propranolol (A), $5 \mathrm{nmol}$ phentolamine (B), $5 \mathrm{nmol}$ yohimbine(C) and 0.5 nmol prazosin (D) into this nucleus on the FLI induced by 15 min hypotension. Rats were sacrificed $1 \mathrm{~h}$ after start of hypotension. Microinfusion of saline resulted in the same picture as that after microinfusion of propranolol (A), not shown here. oc: optic chiasma. Bar $=100 \mu \mathrm{m}$.

\section{Induction of FLI expression by adrenergic agonists}

Microinfusion of $a_{1}$-agonist, methoxamine $(1,10$ and $50 \mathrm{nmol}$ in $0.5 \mu 1, \mathrm{n}=5)$ directed to the SO, could induce abundant FLI-positive cells in the SO. Microinfusion of $a_{2}$-agonist, clonidine, ( 1,10 and $50 \mathrm{nmol}$ in $0.5 \mu 1, \mathrm{n}=5$ ) could seldom induce FLI expression in the SO. The $\beta$-agonist, isoproterenol $(1,10$ and $50 \mathrm{nmol}$ in $0.5 \mu \mathrm{l}$, $\mathrm{n}=5$ ) could not induce FLI expression in the SO either (Fig 4, Fig 5). 
Tab 2. Induction of FLI by microinfusion of $0.5 \mu$ l adrenergic agonists for $50 \mathrm{~min}$ into the supraoptic nucleus. Saline was infused in the same volume at the same speed into the same nucleus as to serve control.

\begin{tabular}{ccc}
\hline Treatment & N & Count of FLI-positive cells \\
\hline saline & 5 & $292 \pm 145$ \\
1 nmol methoxamine & 5 & $838 \pm 206^{*}$ \\
10 nmol methoxamine & 5 & $1406 \pm 293^{* *}$ \\
50 nmol methoxamine & 5 & $2027 \pm 239^{* *}$ \\
1 nmol clonidine & 5 & $318 \pm 114^{*}$ \\
$10 \mathrm{nmol}$ clonidine & 5 & $495 \pm 190$ \\
$50 \mathrm{nmol}$ clonidine & 5 & $531 \pm 245$ \\
$1 \mathrm{nmol}$ isoproterenol & 5 & $243 \pm 107$ \\
$10 \mathrm{nmol}$ isoproterenol & 5 & $273 \pm 116$ \\
$50 \mathrm{nmol}$ isoproterenol & 5 & $219 \pm 113$ \\
\hline
\end{tabular}

$$
{ }^{*} \mathrm{P}<0.01 ;{ }^{* *} \mathrm{P}<0.001 \text {. }
$$

Fig 4. Effects of microinfusion of adrenergic agonists (methoxamine, clonidine and isoproterenol) into the supraoptic nucleus. The figure under each column denotes dose in nmol. Only methoxamine can induce FLI in the supraoptic nucleus. The effects of other agonists are not different significantly from that of microinfusion of the same volume of saline. Comparisons were all made between agonist treated groups and the saline group, $\mathrm{n}=5$. ** $\mathrm{P}<0.01$; *** $\mathrm{P}<0.001$.

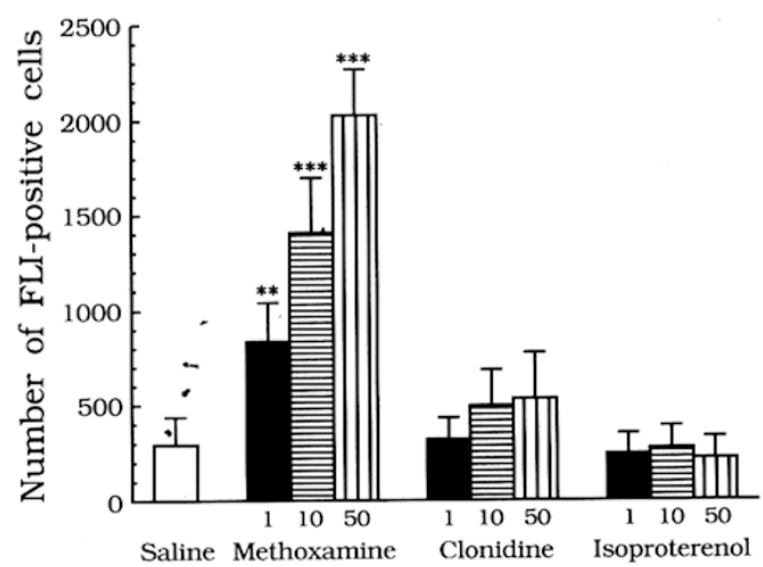

\section{Induction of FLI expression by NA re-uptake inhibitor}

Administration of noradrenaline re-uptake inhibitor, desipramine $\quad(5 \mathrm{nmol}$ in $0.5 \mu \mathrm{l}, \mathrm{n}=5)$ to the SO was performed to see the effect of local accumulation of spontaneously released noradrenaline from the nerve terminals. The time taken for microinfusion and perfusion of the animal was like that for agonists described in the Materials and Methods. FLI was induced in all five animals (mean \pm S.D. was 1241 \pm 457. Comparison between desipramine group and saline group showed highly signigicant difference, $\mathrm{P}<0.01$ ). 
NA mediating Fos-induction in vasopressin cells
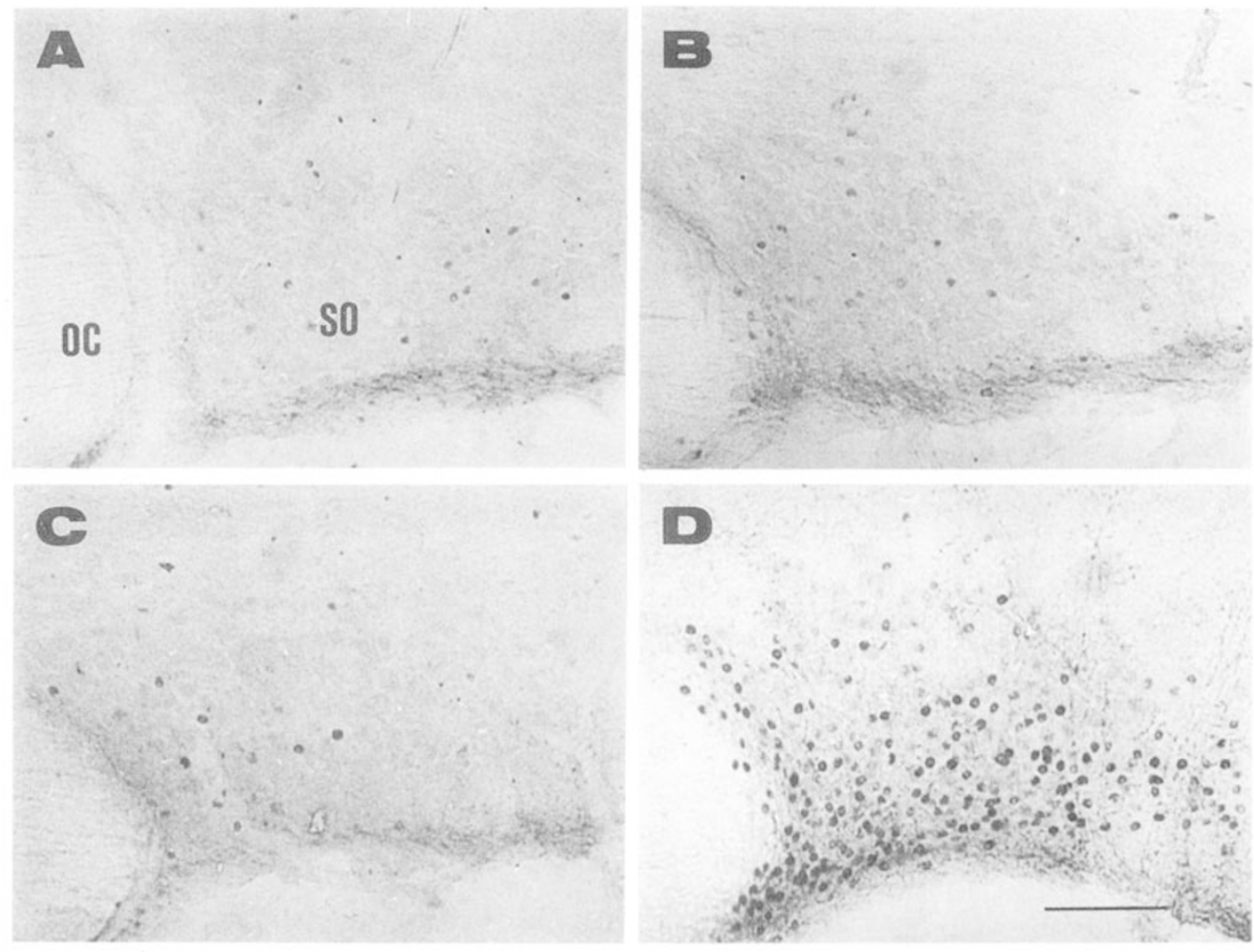

Fig 5. Photomicrographs of the right supraoptic nucleus showing the effects of microinfusion of $0.5 \mu \mathrm{l}$ saline (A), $10 \mathrm{nmol}$ isoproterenol (B), $10 \mathrm{nmol}$ clonidine (C) and $10 \mathrm{nmol}$ methoxamine (D) in the same volume as that of saline into this nucleus. FLI can only be significantly induced by methoxamine. oc: optic chiasma; so: supraoptic nucleus. $\mathrm{Bar}=100 / \mu \mathrm{m}$.

\section{Cell type expressing FLI following agonists or re-uptake inhibitor}

Double staining the FLI-positive cells with anti-VP serum or anti-OT serum respectively in every other section showed that the FLI in the SO induced either by methoxamine $(10 \mathrm{nmol})$ or by desipramine $(5 \mathrm{nmol})$ was largely expressed in the VP-positive cells. There were $986 \pm 183$ out of $1406 \pm 293$ (methoxamine) and 823 \pm 268 out of $1241 \pm 457$ (desipranfine) FLI-positive nuclei in the VP neurons. Fig $6 \mathrm{~A}$ shows numerous fluorescent VP neurons containing dark FLI-positive nucleus, while few OT neurons in the Fig 6C containing the dark nucleus following treatment of desipramine. The result of microinfusion of methoxamine was the same. These results are consistent with that after hypotension[23]. 

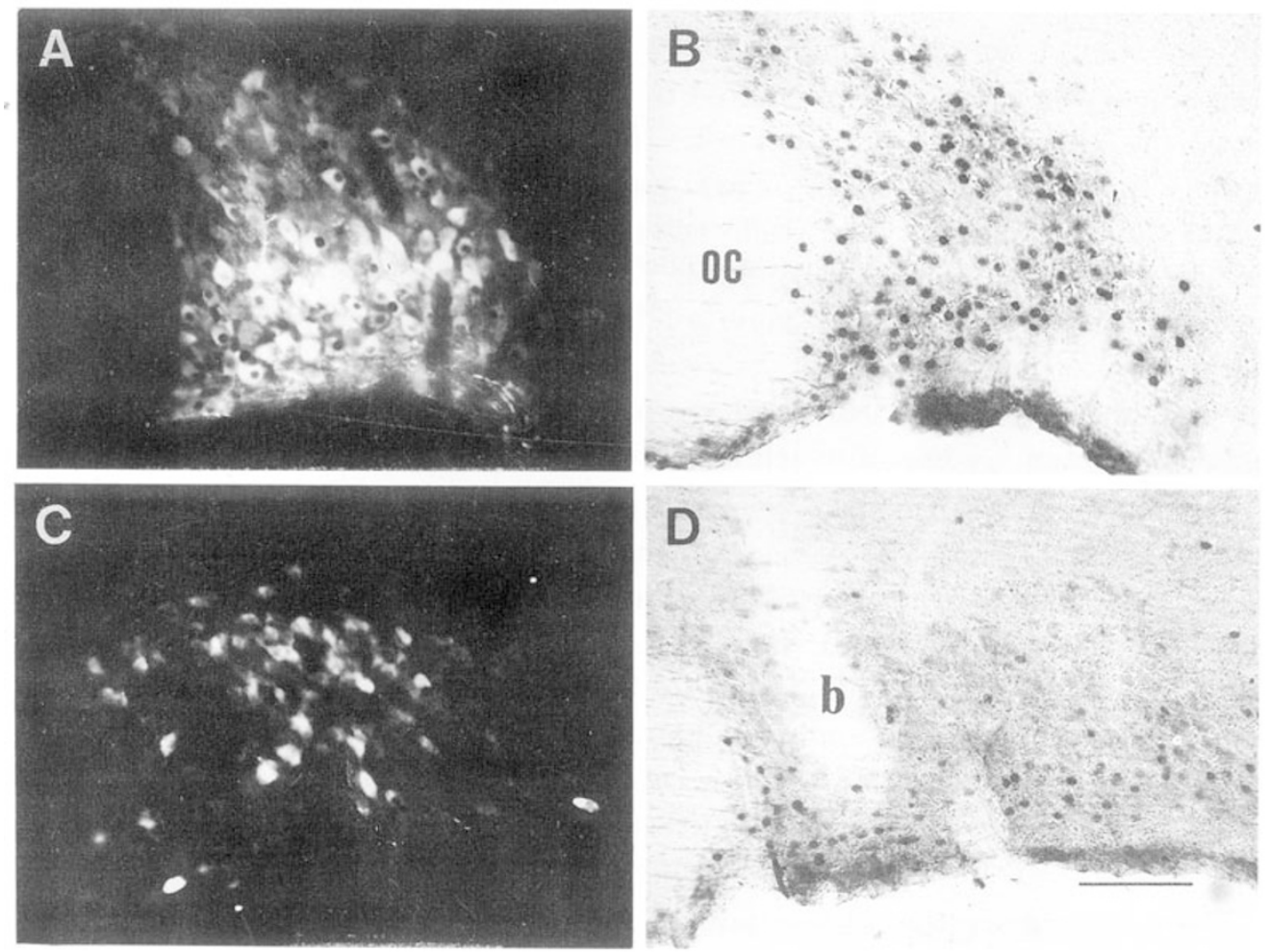

Fig 6. Double labeling of vasopressin (A) or oxytocin (C) and FLI (B,D) in the right supraoptic nucleus of the rat treated with microinfusion of $5 \mathrm{nmol}$ desipramine into this nucleus. A and B are the same section. C and D are the same section. A and C are under ultraviolet light showing fluorescence of VP cells (A) and OT cells (C) respectively. B and D are under normal bright light showing FLI. The FLI-positive cells are largely in the VP cells in A, seldom in the OT cells in C. However, owing to the 40 $\mu \mathrm{m}$ thickness of the section, a portion of the fluorescent cells and their dark nucleus are out of focus. oc: optic chiasma; b: blood vessel. Bar $=100 \mu \mathrm{m}$.

\section{DISCUSSION}

The present results suggest that the FLI-induction by hypotension in the magnocellular endocrine cells in the SO is mediated, at least partially, by an adrenergic pathway via $\alpha_{1}$-receptors. This finding is consistent both with anatoinical data[5, $8,9,17]$ and electrophysiological evidence[7,10,11,12, 18, 19, 20]. The SO contains a dense catecholamine terminal innervation due mainly to noradrenaline[8, 17 , $21]$ and arising primarily from the A1 noradrenergic cell group in the ventrolateral medulla[8, 10, 17]. The NTS projects both to A1 cell group and to the SO directly[5, 
NA mediating Fos-induction in vasopressin cells

$7,8,11,12]$. The electrophysiological experiments showed that the excitatory action of noradrenaline upon the VP cells in the SO was mainly due to activation of $a_{1}$-receptors $[18,20]$. However, it is curious that the adrenergic antagonists did not affect the increased spike activity of putative VP cells in the SO evoked by stimulation of the A1 noradrenergic region[22]. The authors claimed that the increased spike activity so evoked was mediated by ATP[23]. We have not examined the role played by ATP in Fos -induction yet. Nevertheless, stimulation of the A1 region does not necessarily excite the neural pathway underlying the physiological effect of hypotension, owing to that different parameters of stimuli may activate different nerve cells and fibers. Secondly, in the induction of Fos expression, increasing frequency of action potentials may not be the crucial factor[24]. The crucial one is activation of receptors which does not necessarily cause increasing spike activity but may produce depolarization of the membrane and/or cascades of intracellular chemical reactions, some of which may lead to Fos expression.

The blockade of FLI expression in the SO by adrenergic antagonists is far from complete (Fig 4, Fig 5). It seems that other neurotransmitters may associate with NA to mediate the FLI-induction. Some 30 neurotransmitters and neuropeptides have been identified in the PV and SO, some in cell bodies, some in nerve terminals[9, 25]. Among the listed transmitters, noradrenaline, acetylcholine, glutamate, 5 -hydroxytryptamine, histamine, dopamine and $\mathrm{\gamma}$-aminobutyric acid have drawn attention of many investigators[25]. Day et al found that ATP may mediate the excitatory inputs from A1 region to VP cells in the SO[23]. The role played by ATP in the FLI induction in the $\mathrm{SO}$ also remains to be investigated.

There is evidence that stress-induced release of NA interacts with postsynaptic $\beta$-adrenergic receptors, not with $\alpha$-receptors, resulting in induction of c-fos mRNA in the rat brain[26]. This result seems in contradiction with the present one. But what they observed is the mRNA in the whole brain. It has been demonstrated that the excitatory effect of $\beta$-receptor activation is mainly in the hippocampus and cerebral cortex[27]. The size of the SO, even together with the PV, is so small in comparison with the hippocampus and cerebral cortex that the effect of NA on a receptors in the SO or PV must be masked by that on $\beta$-receptor in the whole brain preparation. However, this result together with ours indicate that Fos expression is induced through different receptors in different nerve cells. It has been known that the $\beta$-receptor activation results in activation of adenylate cyclase, and $\alpha_{1}$-receptor are coupled to phospholipase $C$ and phosphoinositide turnover[27]. These facts suggest that Fos expression is induced through different chemical pathways in different type of neurons.

\section{ACKNOWLEDGEMENTS}

The authors wish to express gratitude to Dr. Zhihua JIANG for his help with the immunocytochemical technique. We also thank Dr. Changling LU for a gift 
of anti-oxytocin and anti-vasopressin sera, and Dr. Huayu HUANG for providing us desipramine and Dr. Zhiqi ZHAO for yohimbine and clonidine. This work was supported by the National Natural Science Foundation of China 39270241 and the Chinese Academy of Sciences ks852024.

\section{REFERENCES}

[1] Shen E, Dun SL, Ren C, Dun NJ. Hypovolemia induces Fos-like immunoreactivity in neurons of the rat supraoptic and paraventricular nuclei. J Autonom Nerv Syst 1992; 37:227-30.

[2] Shen E, Dun SL, Ren C, Bennett-Clark C, Dun NJ. Hypotension preferentially induces c-fos immunoreactivity in supraoptic vasopressin neurons. Brain Res 1992; 593:136-9.

[3] Morgan JI,Curran T. Stimulus-transcription coupling in the nervous system: involvement of the inducible protooncogenes. Annu Rev Neurosci 1991; 14:421-51.

[4] Sheng M, Greenberg ME. The regulation and function of c-fos and other immediate early genes in the nervous system. Neuron 1990; 4:477-85.

[5] Cunningham ET, Sawchenko PE. Anatomical specificity of noradrenergic inputs to the paraventricular and supraoptic nuclei of the rat thalamus. J Comp Neurol 1988; 274:60-76.

[6] Lightman SL, Todd K, Everitt BJ. Ascending noradrenergic projections from the brainstem: evidence for a major role in the regulation of blood pressure and vasopressin secretion. Expl Brain Res 1984; 55:145-51.

[7] Raby WN, Renaud LP. Nucleus tractus solitarius innervation of supraoptic nucleus: anatomical and electrophysiological studies in the rat suggest differential innervation of oxytocin and vasopressin neurons. Prog Brain Res 1989; 81:319-27.

[8] Sawchenko PE, Swanson LW. Central noradrenergic pathways for the integration of hypothalamic neuroendocrine and autonomic responses. Science 1981; 214:685-7.

[9] Swanson LW, Sawchenko PE. Hypothalamic integration: organization of the paraventricular and supraoptic nucleus. Annu Rev Neurosci 1983; 6:269-324.

[10]Day TA, Renaud LP. Electrophysiological evidence that noradrenergic afferents selectively facilitate the activity of supraoptic vasopressin neurons. Brain Res 1984; 303:233-40.

[11]Day TA, Sibbald JR. Solitary nucleus excitation of supraoptic vasopressin cells via adrenergic afferents. Amer J Physiol 1988; 254:R711-6.

[12]Day TA, Sibbald JR. A1 cell group mediates solitary nucleus excitation of aupraoptic vasopressi cells. Amer J Physiol 1989; 257:R1020-6.

[13] Head GA, Quail AW, Woods RL Lesions of A1 noradrenergic cells affect AVP release and heart rate during hemorrhage. Amer J Physiol 1987; 253:H1012-7.

[14] Shen E, Sun X, Jiang ZH. Neurotransmitter mediating hypotension induced c-fos expression in the supraoptic nuclei of rats. Soc Neurosci Abst 1993; 19:957.

[15] Liu Z, Lin B, Song C, Wang C, Zhao X, Zhu Y. Preparation and application of antiserum against 8-arginine vasopressin. Acta Zool Sinica 1987; 33:309-15.

[16] Song C, Lin B, Cui R, Liu Z, Zhao X, Wang C, Zhu Y. Radioimmunoassay of oxytocin. Chin J Nucl Med 1987; 7:224-5.

[17] McNeill TH, Sladek JR,Jr. Simultaneous monoamine histofluorescence and neuropeptide immunocytochemistry. II Correlative distribution of catecholamine varicosities and magnocellular neurosecretory neurons in the rat supraoptic and paraventricular nuclei. J Comp Neurol 1980; 193:1023-33.

[18] Inenaga K, Dyball RE J, Okuya S, Yamashida H. Characterization of hypothalamic noradrenaline receptors in the supraoptic nucleus and periventricular region of the paraventricular nucleus of mice in vitro. Brain Res 1986; 369:37-47.

[19] Kimura T, Shoji M, Iitake K, Ota K, Yoshinaga K. The role of central $\alpha_{1}$ and $a_{2}$ adrenoceptors in the regulation of vasopressin release and the cardiovascular system. Endocrinology 1984; 
NA mediating Fos-induction in vasopressin cells

114:1426-32.

[20]Randle JCR, Bourque CW, Renaud LP. $a_{1}$-Adrenergic activation depolarizes rat supraoptic neurosecretory neurons in vitro. Amer J Physiol 1986; 251:R569-74.

[21] Nakada H. Nakai Y. Electron microscopic examination of the catecholaminergic innervation of neurophysin- or vasopressin-containing neurons in the rat hypothalamus. Brain Res 1985; 361:247-57.

[22] Day TA, Renaud LP, Sibbald JR. Excitation of supraoptic vasopressin cells by stimulation of the A1 noradrenaline cell group: failure to demonstrate role for established adrenergic or amino acid receptors. Brain Res 1990; 516:91-8.

[23]Day TA, Sibbald, JR, Khanna S. ATP mediates an excitatory noradrenergic neuron input to supraoptic vasopressin cells. Brain Res 1993; 607:341-4.

[24]Luckman SM, Dyball RE J, Leng G. Induction of c-los expression in hypothalamic magnocellular neurons requires synaptic activation and not simply increased spike activity. J Neurosci 1994; 14:4825-30.

[25]Renaud LP, Bourque CW. Neurophysiology and neuropharmacology of hypothalamic magnocellular neurons secreting vasopressin and oxytocin. Prog Neurobiol 1991; 36:131-69.

[26] Gubits RM, Smith TM, Fairhurst JL, Yu H. Adrenergic Receptors mediate changes in c-fos mRNA levels in brain. Mol Brain Res 1989; 6:39-45.

[27] Nicoll RA, Malenka RC, Kauer JA. Functional comparison of neurotransmitter receptor subtypes in mammalian central nervous system. Physiol Rev 1990; 70:513-65.

Received 10-7-1995. Revised 4-9-1995. Accepted 16-9-1995. 